\title{
Construction and operation of high capacity longwall project : Adriyala experience
}

\author{
B Ramesh Kumar, S Chandrasekhar and B Veera Reddy \\ The Singareni Collieries Company Ltd \\ Kothagudem, India \\ dop@scclmines.com
}

\begin{abstract}
In India, lot of coal reserves exist up to $300 \mathrm{~m}$ depth, are more amenable for extraction by opencast mining. Bulk production is possible with Opencast mining, with low gestation period, more safety and high percentage of extraction compared to underground methods. Hence coal operators are inclined towards opencast mining methods. India is the third largest coal producer in the world and is producing nearly $89 \%$ of coal from opencast mining and $11 \%$ from underground mining (2014-15)[1].
\end{abstract}

In India, the gap between the demand and indigenous availability of coal has been rising. Presently, coal imports are about 99 Million tonnes. The import requirement is projected to be 265 Mt by 2016-17. This gap is likely to widen further beyond XII Plan period leading to requirement of hefty imports. This unacceptable gap can be limited only by an all out effort by domestic coal producers [1].

With depletion of shallow reserves, the future emphasis has to be on faster exploration and underground mining. This calls for meticulous identification of coal blocks suitable for high mechanisation and introduction of state-of-the-art technology from overseas, in addition to possible semi mechanisation of the existing mines. Large scale mechanisation shall be sustained by expanding the service base of Equipment manufactures with supplementation of indigenous spares and parts manufacturing in line with 'Make in India policy'. These high capital intensive systems will not be viable unless global operating standards are achieved in equipment maintenance and utilisation. This demands highly skilled and motivated work force. Suitable planning and systems are to be developed for skill development and for adopting best management practices

However, as shallow seated seams are exhausting at rapid pace and to meet the future requirement there is an urgent need for development and implementation of bulk production technologies for deep-seated deposits in the depth range of $300 \mathrm{~m}$ to $600 \mathrm{~m}$ by underground methods. Coal production at higher rates from underground, particularly at depths more than $300 \mathrm{~m}$, is possible with "Longwall Mining Technology", which is a proven technology worldwide[1].

Accordingly, one high capacity longwall project with an annual capacity of 2.817 MTPA has been commissioned with state of art equipment at Adriyala Longwall Project (ALP). After seeing the performance of Adriyala Longwall Project, SCCL is planning to introduce few more longwalls in near future.
This paper brings out the constructional and operational experiences of high capacity longwall at Adriyala Longwall Project, SCCL.

Keywords_Longwall Mining; Strata Monitoring; Ventilation; Shaft Sinking; Diesel vehicles

\section{INTRODUCTION}

To meet the increasing demand of coal from power sector and to regulate opencast projects, SCCL envisaged the opening up of deep shaft blocks for large-scale production. At present the existing pithead of NTPC, 2600 MW thermal power station, Ramagundam is being supplied by three opencast projects of SCCL $(10.20 \mathrm{Mt})$ out of its total requirement of $12.50 \mathrm{Mt}$. In the long run, over a period of ten years, the reserves in the above mines are depleting and opening up of $2.817 \mathrm{Mt}$ capacity Adriyala Longwall project along with other deep shaft projects in Ramagundam will help to fulfil the coal supply to retain the pithead nature of NTPC Ramagundam power station.

Mean while SCCL started construction of 2X600MW plant and will be put in to commercial operations by May2016. Further, NTPC is enhancing its capacity by setting up 2X800MW thermal plant in near future.

Accordingly, SCCL planned bulk production Longwall Project for the first time in India at Adriyala mine in Godavarikhani to extract the coal reserves lying below $350 \mathrm{~m}$ depth. This project lies at a distance of $65 \mathrm{KM}$ from Karimnagar and $225 \mathrm{KM}$ from Hyderabad.

\section{A. Adriyala Longwall Project:}

Revised Cost Estimate (RCE)-I was approved by GoI on 24.12.2009 and RCE-II was approved by GoI on 27.08.2014. The project is having 78.597MT of extractable reserves within the depth range of $294-644 \mathrm{~m}$. The project life is about 35 years with a rated production of 2.817MTPA.

The longwall equipment consists of EL 3000 shearer with $2245 \mathrm{KW}$ installed capacity, Armoured Face Conveyor(AFC) with installed capacity of $2565 \mathrm{KW}$, Beam Stage Loader(BSL) of $400 \mathrm{KW}, 146$ shields of capacity $2 \mathrm{X} 1150 \mathrm{t}$ and $1.75 \mathrm{~m}$ width, $2 \mathrm{x} 4.5 \mathrm{MW}$ of $11 \mathrm{KV} / 3.3 \mathrm{KV}$ transwitches and $3 \mathrm{Kms}$ long, $1600 \mathrm{~mm}$ wide gate belt with $3 \times 315 \mathrm{KW}$ drives. 
B. The following new technologies have been introduced at the project for the first time:

- Punch entry (Direct access to coal from Opencast highwall)

- $11 \mathrm{KV}$ power transmission to $\mathrm{UG}$ (for less voltage drop)

- Pre tensioned Cable bolting (For effective roof support)

- Automation systems (For sequence control/less manual intervention)

- $400 \mathrm{KW}$ high capacity fan (To supply more air with high water gauge)

- Diesel transport vehicles (FBL) (For flexible, speedy $\&$ safe equipment transportation)

- Floor Concreting in underground (For Diesel vehicle movement with heavy equipment)

- VFD controlled un-manned Belt conveyor system (For soft starts and power conservation)

- Mine cruiser (for faster and safe transport of men)

- Air chilling plant (To create comfortable environment conditions)

\section{CONSTRUCTION OF High CAPACITY LONGWALL}

\section{A. Exploration:}

A total of 95 bore holes have been drilled with the density of about 25 boreholes per sq.km for delineation of Adriyala Longwall block. Coring was done in 19 bore holes and quality of the coal seams was obtained from 61 bore holes. Geo- engineering data is generated from 12 bore holes and Geo- Physical logging was carried out in 44 bore holes using analogue model series-III logging system $\mathrm{M} / \mathrm{s}$ Mount Sopris Instruments Ltd, USA and digital logging system of M/s Robertson Geo logging of UK.

\section{B. Punch Entries:}

The unique feature of the project is that the main entries are planned through the adjacent rise side open cast mine. Aplatform of about $200 \mathrm{mx} 150 \mathrm{~m}$ is prepared adjacent to highwall at No.1 Seam floor (120m depth from surface). The high wall was dressed at proposed locations of Punch Entries in No.1 Seam then RCC blocks of $5.5 \mathrm{mx} 3.6 \mathrm{~m} \times 1 \mathrm{~m}$ dimensions were spread on the floor from high wall for a length of $15 \mathrm{~m}$. The gap between highwall and blocks was covered to prevent fall of loose boulders from highwall. The highwall was stabilized with cable bolting and cement injection along the periphery of the proposed Punch Entry. Then four Punch entries of size $5.50 \mathrm{~m} \times 3.60 \mathrm{~m}$ were driven in top section of No. 1 Seam for a length of $1.80 \mathrm{kms}$ at 1 in 5 gradient using road headers, as shown in Fig.1 (a) \&(b). Initially, goal post supporting was done for $20 \mathrm{~m}$ distance from entry of drivage in addition to roof bolting. These are the main entries for the project and planned for man riding system, trunk belts, diesel vehicles roadway and haulage system one in each punch entry

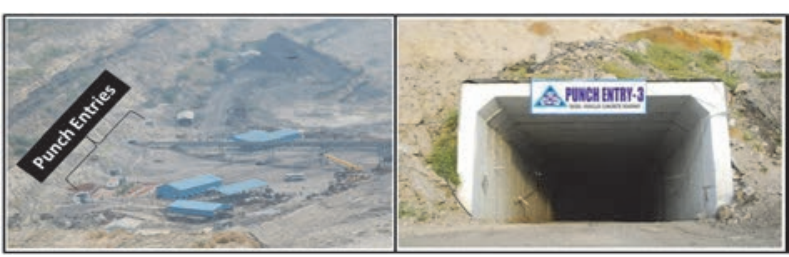

Fig. 1. (a) \& (b) Punch entries layout and one of the Punch entries

C. Mine Development:

The drivage of Trunk road ways $(5.50 \mathrm{~m} \times 3.60 \mathrm{~m})$ and Gate road ways $(5.20 \mathrm{mx} 3.60 \mathrm{~m})$ was made using twin bolters mounted Road Headers (DOSCO, LH 1400 Model). 25Kms of drivage was made during last five years using 05 no's of Road headers. The gate roadways are supported with $2.4 \mathrm{~m}$, $\varnothing 22 \mathrm{~mm}$ shear pin bolts with full column resin grout and rigid wire mesh. Secondary supporting was done in gate road ways with $6.1 \mathrm{~m}$ long pre-tensioned cable bolts to take care of longwall abutments ahead of face. The installation face widened to $8 \mathrm{~m}$ and could be successfully supported by adopting pre-tensioned cable bolts, for the first time without erecting vertical support. The details of underground workings are shown in Fig.2.

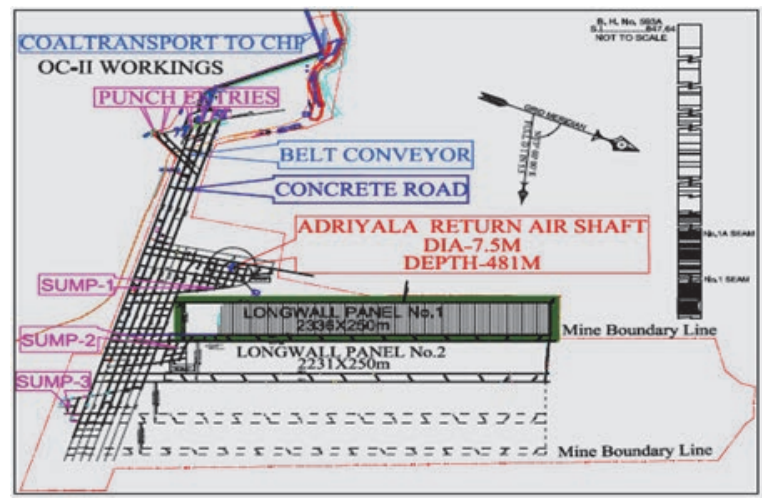

Fig. 2. Plan showing the Underground workings of ALP

\section{Shaft sinking:}

At Adriyala Shaft Project, Sinking and lining of a return air shaft of finished diameter of $7.50 \mathrm{~m} \&$ depth of $468 \mathrm{~m}$, with necessary insets was done. The shaft sinking arrangements are as shown in Fig.3 (a) and (b)

Lining was done with reinforced cement concreting of $300 \mathrm{~mm}$ thick M-20Grade, Containing coarse aggregate of $20 \mathrm{~mm}$ down gauge of approved quality (in conformity with IS:456-1978).

While sinking return air shaft, challenges due to unconsolidated strata, running sand, shale and clay layers at several horizons were encountered. Water seepage was more than 600GPM.To counter the above problems the following were done

- Reinforcement of surface strata with concrete injection up to a depth of $30 \mathrm{~m}$. 
- Drilling of boreholes from the existing shaft bottom to 60 Level gallery (underground working) for draining out the seepage water from the shaft/progressive shaft bottom.

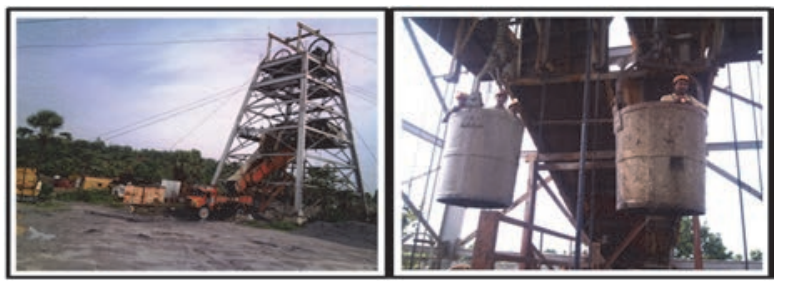

Fig. 3. (a) and (b) shaft sinking arrangements

\section{E. Ventilation:}

Adriyala Project is planned to work in the depth range of $300 \mathrm{~m}$ to $640 \mathrm{~m}$. The geothermic gradient is about $69 \mathrm{~m} /{ }^{\circ} \mathrm{C}$. to meet the ventilation requirements, a study was done by ISM, Dhanbad and according to therequirement mine drivages were developed. Adriyala Mine is accessed by four Punch entries and one shaft. Two main fans of $400 \mathrm{kw}$ and $15,000 \mathrm{Cu} . \mathrm{m} / \mathrm{min}$ and fourbooster fans of $75 \mathrm{kw}$ of 4,000 $\mathrm{Cu} . \mathrm{m} / \mathrm{min}$ capacities were procured from M/s Zitron, Spain and installed. Fig.04 shows the view of Main Fan.

Initially, when longwall panel started wet bulb temperature was about $28^{\circ} \mathrm{C}$. But after working for $450 \mathrm{~m}$ retreat, the face wet bulb temperature gradually increased to $32^{\circ} \mathrm{C}$ due to heat generation from working machinery, large goaf area, hot strata water $\left(35^{\circ} \mathrm{C}\right)$ flowing along the bottom gate roadways and large volumes of coal cutting in the face.

The following measures were taken to improve environmental conditions at face.

- All pumping stations, belt road way and all drives were given separate ventilation splits to eliminate addition of heat to longwall intake air.

- Small 12 tonnes capacity air conditioners are provided to supply cool air to critical electrical i.e., face load centre and pump load centre.

- 20HP fans are installed with ducting to supply fresh intake air to all important electrical controls.

- One Ø8" pipe line was laid in TG-2 road way for carrying all the goaf water directly to sump.

- All the water is diverted to covered drains/pipe lines to reduce humidity.

\section{F. Out bye conveyor system:}

Conveyor system of $9 \mathrm{Km}$ long from longwall gate belt (Underground) to Coal Screening Plant(CSP) is installed and commissioned with 11 Conveyor belts with installed capacity of about $12 \mathrm{MW}$. Huge civil foundations were prepared, some of which were on dumped over burden (OB). To prepare the civil foundations on Over Burden dumps, dumps were excavated up to $10 \mathrm{~m}$ deep and then filled and compacted layer by layer with suitable material up to required level. Then required excavations and civil foundations were made in the compacted zone as shown in fig. 05. The conveyor system consists of nine Steel cord belts \& 02 PVC belts of $1600 \mathrm{~mm}$ width, $3500 \mathrm{TPH}$ capacity, $4.0 \mathrm{~m} / \mathrm{s}$ speed and Variable Frequency Drives (VFDs) as shown in fig. 06.

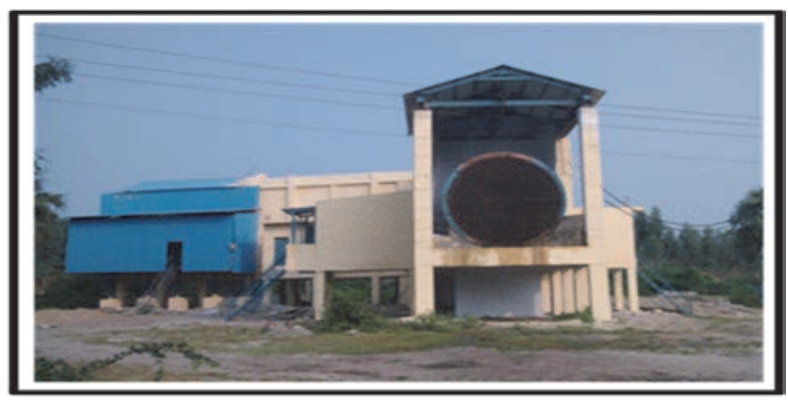

Fig. 4. Main Mechanical Ventilator

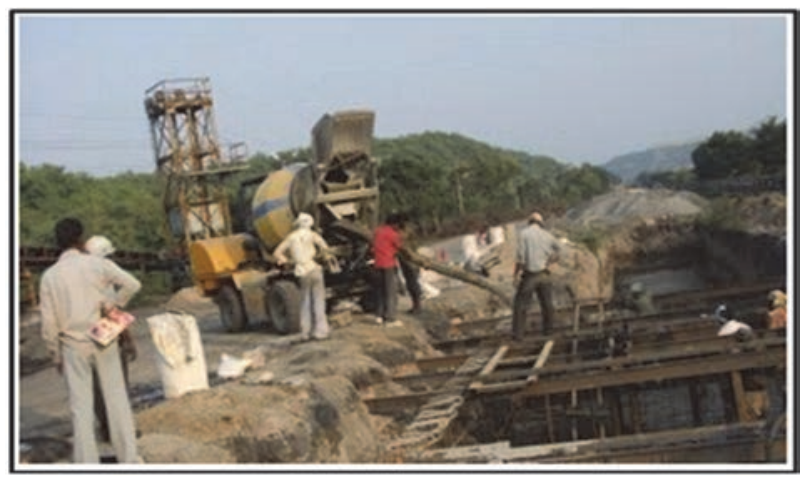

Fig. 5. Civil foundation works

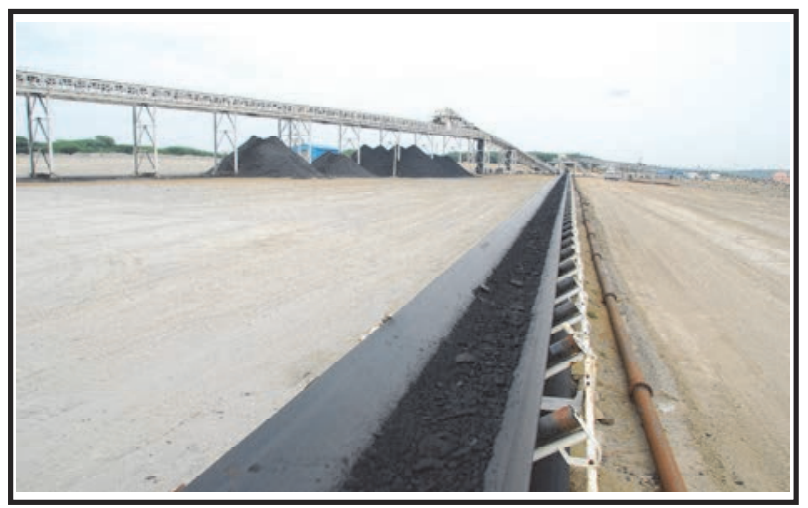

Fig. 6. High capacity belt conveyor system

\section{G. Training:}

No. of teams consisting of officers, supervisors and technicians were trained in Germany, Australia and China on Longwall mechanization and Diesel vehicles. Further training was given to Adriyala team in Mini build on surface for 03 months and also training on $11 \mathrm{KV}$ equipment was given by Victor, UK. In view of the large Underground mine and many new technologies have been adopted in the project, a training centre was provided specially for Adriyala to give initial and refresher training to the longwall employees. 


\section{H. Power supply system:}

$11 \mathrm{KV}$ transmission system was introduced in Indian underground coal mine for the first time. A total of $7.5 \mathrm{Km}$ overhead lines and $19 \mathrm{KM}$ of cable is laid to meet the huge power requirements. Auto power factor correction unit was installed for the first time to curtail the wasteful energy loss. The total connected load of the project was $24 \mathrm{MW}$ and increased to $30 \mathrm{MW}$ with the addition of air chilling, Nitrogen and Compressor plants.

\section{Floor Concreting:}

To facilitate transport of Longwall equipment using diesel vehicles, one of the trunk road ways with weak floor was concreted with M-40 grade self compacting concrete for a length of about $2.0 \mathrm{Km}$. Longwall panel top gate was also concreted for about $200 \mathrm{~m}$ length near coal floor from trunk roadway to reach of stone floor in bottom section. In gate roadways, stone floor is strong enough to take load of heavy longwall equipment.

Batching plant was installed on surface; from there concrete transported to Punch entry mouth by mobile mixer and then concrete trolley with mixer is taken to bottom most point of the road way with the help of direct hauler and floor mounted track. Concreting started from dip most point and proceeded to rise side. Before concreting, the solid floor is exposed and the bigger depressions are filled with sand before putting concrete on the floor. $2.0 \mathrm{kms}$ concreting pavement at not more than 1 in 4 gradient @1m/day.

The surface of concreted roadway is provided with deep grooves to provide grip to the rubber tyred diesel vehicles. Cross drain of 2" groovealong road width is provided at every $200 \mathrm{~m}$ interval along the concreted roadway as shown in fig 7 (a)\& (b).
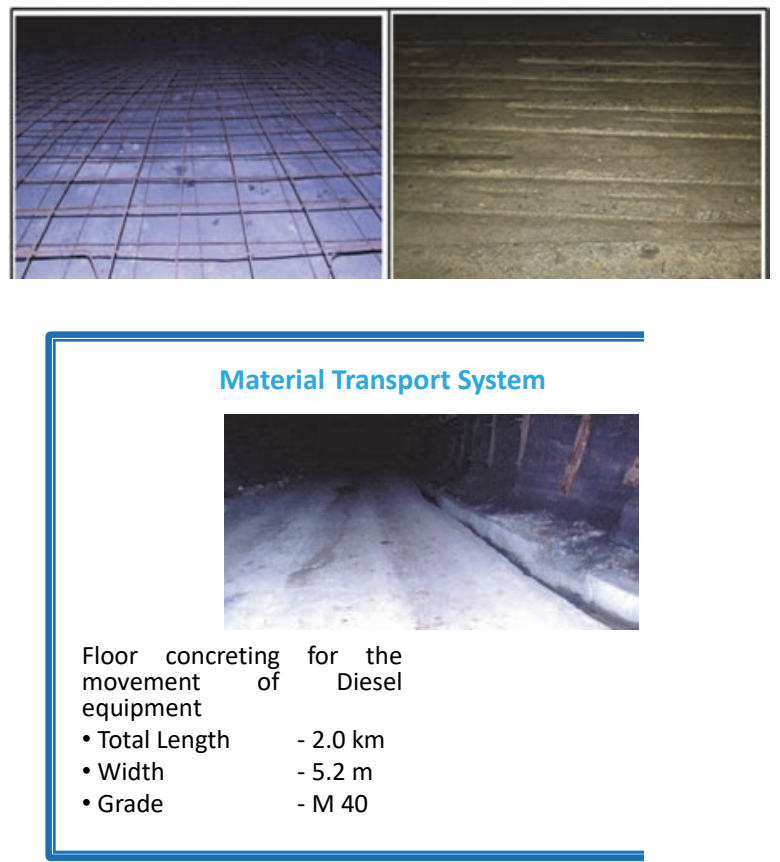

Fig. 7. (a) \& (b) Concrete roadway for movement of Diesel Vehicles

\section{J. Transport \& Installation of Longwall equipment using diesel vehicles:}

Diesel driven free steered vehicles are deployed for material and longwall equipment transport. The longwall equipment weighing about 35-50 tonnes were transported at 1 in 4 gradient on the concreted road way successfully.

Total equipment transportation from surface to longwall face and installation was done using diesel vehiclessupplied by $\mathrm{M} / \mathrm{s}$ Caterpillar - Australia.

Risk assessment was done and safe operating procedures were prepared and implemented for transport of heavy equipment. Vehicle is subjected to braking efficiency on test ramp of 1 in 4 gradient on surface before sending any diesel vehicle with heavy load belowground. Approx. 9000T of equipment was transported by SH660D (50T), CL-210 (10T), CL-215 (15T) and SH-150 (35T) vehicles. Fig 8a \& b shows the break testing on ramp and transportation of PRS with diesel vehicle.

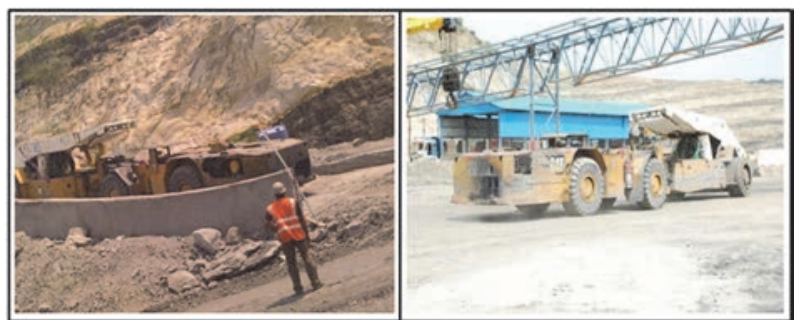

Fig. 8. (a) \& (b) Brake testing on RAMP \& Transportation of PRS with diesel vehicle

\section{OPERATIONAL ASPECTS OF ADRIYALA LONGWALL PROJECT}

\section{A. Longwall face operations:}

1) Face cutting operation:

The basic cutting sequences in Longwall are BiDirectional (Bi-Di), Uni-Directional (Uni-Di). At Adriyala face cutting is being done in Uni Di method. The Uni Di method is a simpler system to operate, enables operators to keep away from high dust concentrations, can allow the loading onto the coal haulage system to be made more even and can at times equal or even exceed Bi-di production. In the event of roof cavities and poor strata conditions and to move creep upward Bi Di cutting method is being followed at Adriyala.

2) Creep control, Face alignment and Horizon control:

These three are very important parameters in successful operation of longwall, to be monitored continuously and to be maintained within the acceptable levels. The creep is stabilised by maintaining the staggering of about $20-25 \mathrm{~m}$ (keeping the bottom gate $20-25 \mathrm{~m}$ ahead of tail gate) between two gate roadways. The face is kept at an obliquity of 4 degrees (half of the seam inclination) from perpendicular. Face alignment and horizon control play a key role in mitigating the strata control issues and in increasing the life of face equipment. The proper face alignment and horizon control are ensured in every shift physically and every alternative day face offsets and heights 
are taken and plotted by surveyor and shown to panel incharge. Very strict operational discipline is required to maintain the above parameters within the acceptable levels.

\section{3) Automation and SCADA (Supervisory control and Data} Acquisition):

Leg pressure in PRS (Powered Roof Support) system, Face straightness, Concentration of operating fluid are monitored, recorded and displayed, Concentration of operating fluid for the PRS system is monitored at the power pack by automatically measuring the quantities of water and concentrated emulsion added in the mixer to determine the concentration of the emulsion added to the tank. Total quantities added over time are also recorded to indicate total fluid usage / leakage.

Shearer Initiated Roof Support Advance (SIRSA) with batch control and auto horizon control are provided. Shearer condition and location is monitored, displayed \& recorded. Automation system includes monitoring and visualizing the installed shearer sensors such as Voltage, Motor Temperature, Ranging Arm Oil Temperature, Power Pack Oil Temperature, Traction Oil Temperature, Power Pack Oil Level, Cooling Water Pressure, Cooling Water Flow, Drum Pressure, Drum Water Flow, Machine Mode, State Automation, Face Along Angle, Face advance angle, Cutter Current, Pump Current, Haulage Current, Coalsizer Current, Transformer Current, Position, Arm Height and Speed of the shearer.

AFC tensioning is monitored by electric tensioning device at tail gate, displayed \& recorded, Snaking control is done by definition of snaking area and web width. These will be controlled and monitored, displayed \& recorded,Amperage and Voltage are controlled by electrical energy train and will be monitored, displayed \& recorded at the energy train and Diagnostic information/Condition monitoring for Shearer, PRS (with sensors for Leg Pressure, Stroke Advancing Ram cylinder, Stroke of Flipper cylinder. Based on these sensors values Shield Position, Conveyor Position and Convergence Monitoring (Pressure $\mathrm{dP} / \mathrm{dT}$ ) can be calculated and monitored), AFC(with sensors for Motor current, Gearbox: Coupling pressure, Cooling Oil pressure, Temperature 2 x, Difference Pressure Filter, Input Speed, Output Speed, Oil level and System pressure) can be monitored by automation system. The power pack and BSL is monitored by the electrical installation (via SCADA). All information shall be monitored, displayed \& recorded.Convergences is measured by PRS system, displayed \& recorded. Convergence measurements are done by measurement of the change of shield leg pressure as a $\mathrm{dP} / \mathrm{dT}$ value and visualized by Caterpillar Automation.The entire latest configurations of online monitoring are provided.

\section{4) Water Management:}

Periodical falls of overlying strata are taking place in the goaf with retreat of longwall face. During each periodic fall, the overlying strata breaks and disturb overlying water bearing strata in turn water flowing into goaf through the cracks. The water coming from goaf will increase with each roof fall. It is expected that about 1000GPM of water will be flowing from the goaf by the end of panel.

Currently, about 700GPM water is coming from longwall goaf. The water from goaf flows through bottom gate and immediate out bye cut through and from there through the cleaning chambers in to 08 " pipe line laid in TG 2 and directly delivered in to SUMP 2 by gravity which has a capacity of 27 lakh gallons.

\section{B. Pumping arrangement:}

Two main sumps are prepared one for the total mine and another for longwall panel no.1 with the capacities of 56lakh gallons and 27lakh gallons respectively.The installed pumping capacity is about $3500 \mathrm{GPM}$ with 4 nos $350 \mathrm{HP}$ and 1 No 600KW high head pump against the expected make of water of about $2500 \mathrm{GPM}$ from the mine. Planning to increase the pumping capacity to $4500 \mathrm{GPM}$ to take care of surges.

Lot of slush/coal pieces are carried along with huge amount of water flowing along thebottom gate roadways and gets deposited in the sump if proper cleaning arrangements arenot made with cleaning chambers provided enroute.

\section{Subsidence:}

Subsidence pillars were constructed at $30 \mathrm{~m}$ grid pattern to study the subsidence over LWP No1. The LWP No1 was started on 15.10 .2014 and till now about $1500 \mathrm{~m}$ retreat was completed. Over longwall panel up to $1100 \mathrm{~m}$ distance an external OB dump was there (from 0 to $500 \mathrm{~m}$ it is $60 \mathrm{~m}$ height and 500 to $1100 \mathrm{~m}$ it is $45 \mathrm{~m}$ height). The main fall occurred after retreat of $83 \mathrm{~m}$ in the month of December2014 , but the first subsidence was noticed in the month of april-2015 and progress was $400 \mathrm{~m}$. Hence the first subsidence was noticed after progress of about $350 \mathrm{~m}$ to $400 \mathrm{~m}$. First $150 \mathrm{~m}$ from the face start line, there was no subsidence due to barrier effect and Subsidence further occurring regularly.

The subsidence trough have a maximum vertical movement of about $1400 \mathrm{~mm}$ on original ground and $1900 \mathrm{~mm}$ over the OB dumps within the panel with the maximum subsidence point shifted at about $50 \mathrm{~m}$ towards the dip side from the panel center.Cracks of width $5 \mathrm{~mm}$ to $20 \mathrm{~mm}$ were observed at the dip side of the panel. However distinct cracks attributing to subsidence could not be clearly seen on the rise of the panel. The cluster of tensile cracks can be seen mostly over the dip side panel boundary and over the panel barrier.

\section{Strata Control Management during development and longwall retreat[2]:}

\section{1) Gate roadways:}

Initially roof disturbances were observed and on two occasions cavities occurred in gate road ways driven in bottom section taking middle clay in to working section. Later geological mapping and litho logical study was done and working section has been changed by leaving middle 
clay in the overlying strata with $1 \mathrm{~m}$ coal underneath it, which improved the stability of gate roadways.

\section{2) Cut Throughs:}

The cut throughs were driven in between two gate roadways (MG1\&TG2) at $200 \mathrm{~m}$ interval. Initially cut throughs were driven across the major horizontal stress direction, in which severe strata control problems were encountered and cavities also taken place. Later the direction of cut throughs have been changed and aligned with major horizontal stress direction which eliminated all strata problems. Initially gate roadways were supported with roof bolting with linked wire mesh in the roof. Later rigid wire mesh has been introduced in place of linked wire mesh to reduce supporting cycle time and to improve the supporting efficiency of the system. The roof conditions and drivage rates have been improved with introduction of rigid wire mesh.

\section{3) Face dip widening:}

Strata problems were encountered while widening longwall installation face with $8 \mathrm{~m}$ width. As per the recommendation of Geotech consultant, Pre tensioned cable bolting $(6.1 \mathrm{~m})$ was introduced for the first time for better strata control and to eliminate vertical support in face dip to facilitate the movement of Diesel Vehicles. After supporting with cable bolts, the face dip was widened to $8 \mathrm{~m}$ without any strata control problems.

\section{4) Gate roads monitoring:}

Tell tales were installed for every $50 \mathrm{~m}$ interval to monitor the bed separation at two horizons and convergence stations were installed for every $25 \mathrm{~m}$ interval to monitor the convergence in Gate roadways.

\section{5) Main and periodic weightings in longwall face:}

Regular falls are taking place in the longwall goaf without any strata problems in the face. First local fall occurred after retreat of $44 \mathrm{~m}$ and main fall occurred after retreat of $82 \mathrm{~m}$ (22,000sq.m). Subsequently periodical falls are taking place at an interval of 16 to $18 \mathrm{~m}$. During weightings, mid zone supports (about100-120 out of 146 supports) attaining yield pressure of 450 bar and pressures are being released after completion of 5/6 mining cycles. Breaker line is formed parallel to face and about $1 \mathrm{~m}$ ahead of the face and water seepage is observed with negligible face convergence during every weighting.

\section{6) Surface borehole extensometer:}

To study the caving behavior of the LWP No1 above No1 seam of ALP, Surface multipoint borehole extensometer was installed at $1130 \mathrm{~m}$ location from the longwall installation face which located at the middle of the face (Equal distance from the Main gate and Tail gate). The installation was completed in the month of June-2015, when face was about $500 \mathrm{~m}$ away.

Two anchors were installed at two horizons .One anchor is located at $275 \mathrm{~m}$ depth from the surface (i.e $125 \mathrm{~m}$ above the No1 seam roof) and second anchor is located at $230 \mathrm{~m}$ depth from the surface (i.e $170 \mathrm{~m}$ above the No1 seam roof). The first bed separation of $40 \mathrm{~mm}$ was noticed on $02-01$ 2016 when the face crossed by $60 \mathrm{~m}$. The total bed separation from surface to $230 \mathrm{~m}$ is $210 \mathrm{~mm}$ and from $230 \mathrm{~m}$ to $275 \mathrm{~m}$ is $90 \mathrm{~mm}$ and the total cumulative bed separation was about $300 \mathrm{~mm}$ when the face was $260 \mathrm{~m}$ outbye side, after that the beds were stabilized and no further movement was noticed. The subsidence at that location was about $0.9 \mathrm{~m}$.

From the above, it is clear that the overlying strata is falling at regular intervals and filling the void. The strata movement is active between $60 \mathrm{~m}-260 \mathrm{~m}$ behind the face.

\section{E. Goaf Inertization:}

Nitrogen Flushing:CSIRO, Australia has recommended to install Nitrogen Plant to carry out Longwall goaf inertization continuously as a proactive measure to prevent spontaneous combustion in LW goaf. Accordingly $\mathrm{N}_{2}$ plant was installed with a capacity of $800 \mathrm{Cu} . \mathrm{m} / \mathrm{hr}$ and $\mathrm{N}_{2}$ flushing is being done. To increase the rate of flushing, a new Nitrogen plant of $1200 \mathrm{Cu} . \mathrm{m} / \mathrm{hr}$ capacity is under installation and likely to be commissioned by October, 2016. In addition to $\mathrm{N}_{2}$ flushing, $\mathrm{CO}_{2}$ is also being flushed at the rate of 3 Tonnes/day in to the goaf.

\section{F. Air chilling plant:}

To provide cool ventilating air to the workings it was proposed to install Air conditioning system at ALP. A study was carried out by ISM,Dhanbad for the design of Air cooling system. The procurement of above chilling plant was delayed due to some technical reasons. Meanwhile, to meet immediate requirement of longwall face, outsourced air chilling plant of 1400TR was installed at mouth of Punch Entry-5 (PE-5) as shown in Fig. 9 (a) \&(b). About $3500 \mathrm{Cu} . \mathrm{m} / \mathrm{min}$ of chilled air is being supplied at 11 to $13{ }^{\circ} \mathrm{C}$ at the entry of PE-5. From there cooled air is ventilated to longwall face through a separate air way via PE-5 and MainGate-1. After commissioning of air chilling plant and supply of cool air, the temperature has been brought down by 3 to $4{ }^{0} \mathrm{C}$. Efficiency and effectiveness of men and machinery increased considerably.

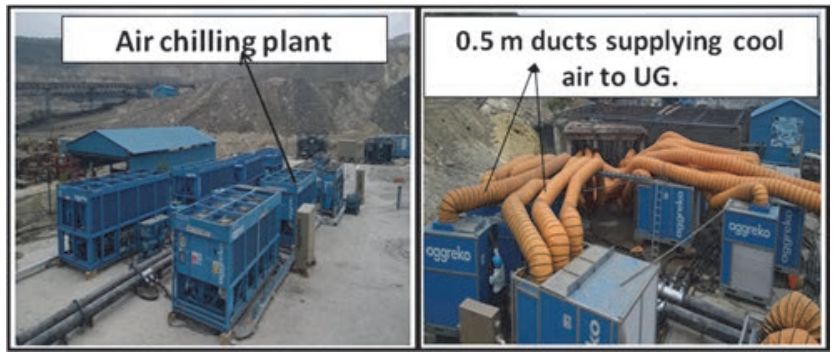

Fig. 9. (a) \& (b) Layout of Air Chilling Units \& Ducting Arrangement

\section{G. Transport of men with diesel Mine cruisers:}

One chair car system and one chair lift system covering a distance of about $2.5 \mathrm{~km}$ in main trunk roadways is provided for men conveyance. Two more chair lift systems 
are under installation on RAMP and PE mouth to transport all the men by chair lift system except Longwall and development drivage teams.

For the purpose of longwall and road header production crew a diesel mine cruiser of M/s Bird Machines, South Africa supplied by $\mathrm{M} / \mathrm{s}$ Bharat Earth Movers Limited (BEML), India is provided first of its kind in Indian coal industry. The diesel mine cruiser can carry 16 persons and can negotiate a maximum gradient of 1 in 4 . After successful trials five more machines will be deployed.

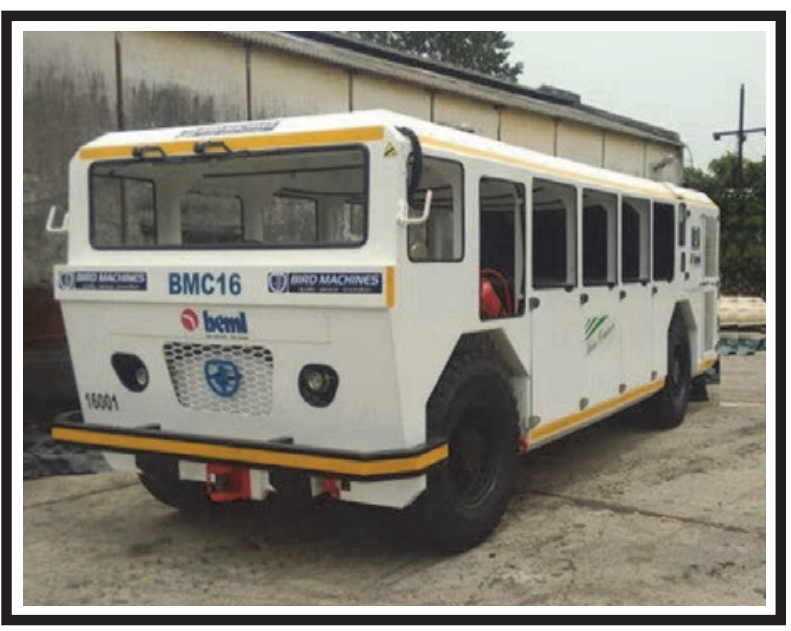

Fig. 10. Mine Cruiser for men transport

\section{H. Performance:}

The first longwall panel was commissioned on 15.10.2014 with a rated capacity of 2.5 MTPA. The length of the face is $250 \mathrm{~m} \&$ the panel length is $2333 \mathrm{~m}$, with reserves of about $3.36 \mathrm{Mt}$. So far $(31.07 .2016) 3.00 \mathrm{Mt}$ coal has been extracted. Adriyala records a monthly highest production in April-2016 with an output of 2.53LT \& daily highest production of 13,187Tonnes on 29.02.2016. Initially, the performance was not satisfactory due to failure of Variable Frequency Drives (VFD) and loop take up winch hydraulic motors on gate belt and few components in face load centre electricals. Gradually the production got stabilised and currently producing about 8000-9000TPD. The equipment has produced $3.0 \mathrm{Mt}$ as on date.

\section{Productivity \& Profitability[4]:}

Productivity and profitability figures of different technologies of SCCL are given in the Table-I for the year 2014-15. From the above, it s evident that the productivity and profitability of Adriyala Longwall are on par with opencast mining. The cost of production of other underground technologies is very high except Continuous Miner and incurring huge losses.

\section{J. New technologies still to be introduced at $A L P$ :}

- Bolter Miner for drivage of trunk \& gate roadways (Order has been placed)

- Pan line bolter for preparation of salvage chamber

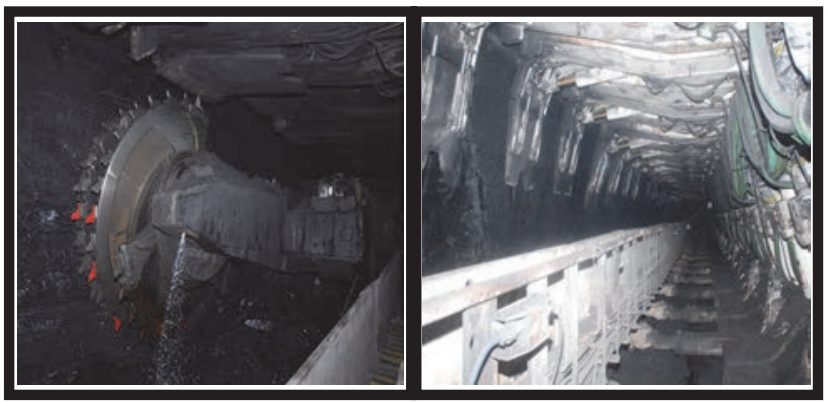

Fig. 11. Adriyala Longwall Project - Longwall Face

TABLE I. PRODUCTIVITY \& PROFITABILITY OF DIFFERENT TECHNOLOGIED OF SCCL

\begin{tabular}{|l|l|l|l|}
\hline Technology & $\begin{array}{l}\text { Production } \\
\text { in LTs }\end{array}$ & $\begin{array}{l}\text { Cost of } \\
\text { prod. In } \\
\text { Rs/T }\end{array}$ & OMS \\
\hline Hand section & 7.28 & 9900 & 0.52 \\
\hline Road Headers & 0.87 & 12793 & 0.52 \\
\hline SDL & 50.13 & 4226 & 1.03 \\
\hline LHD & 17.79 & 4245 & 1.21 \\
\hline Continuous Miner & 6.78 & 2471 & 3.35 \\
\hline Opencast & 423.33 & 1414 & 12.18 \\
\hline $\begin{array}{l}\text { Adriyala Longwall } \\
\text { (2015-16) }\end{array}$ & $\mathbf{1 7 . 1 3}$ & $\mathbf{1 4 2 0}$ & $\mathbf{1 0 . 6 8}$ \\
\hline $\begin{array}{l}\text { Adriyala total mine } \\
\text { (2015-16) }\end{array}$ & $\mathbf{1 8 . 5 2}$ & $\mathbf{2 0 3 4}$ & $\mathbf{5 . 2 0}$ \\
\hline
\end{tabular}

- Plastic wire mesh for salvaging of LW Panel No.1

- Tube bundle system for monitoring of longwall goaf gases

- Refugee chamber (a specialized escape chamber) for escape of persons in case of fire or other hazards in underground)

- Pneumatic wipers/suitable wipers for high capacity and high speed belting system

- Small diesel vehicles for cleaning of debris / slush / spillage coal along belting system in underground

\section{OBSERVATIONS}

- Initially there were some apprehensions on workability of Bolter Miner (BM) at Adriyala Longwall Project due to its steep gradient and stone cutting in the floor in the gate roadways. Hence a decision was taken to use newly supplied Road Header (RH) machines for drivage of roadways to avoid surprises with BM as RH technology is well established system for decades. During the development of 2nd panel, some improvements were brought in quality of roadways with RHs with the experience of 1 st panel drivages. However, $\mathrm{RH}$ drivages are not meeting the project requirements due to their inherently low development rates, inability to provide a quality roadway conditions suitable for High capacity LW equipment and requirement of more man power. Hence a decision was taken to introduce BM for drivage of roadways and order is placed for deployment of BM. The BM is likely to be commissioned by November, 2016. 
- Initially, the project operations were interrupted by opencast activities like blasting and movement of heavy machinery movement. Later, the OC workings progressed well away from Punch entries and there was no interference.

- Once an abnormal flow of water of about 1200 GPM was observed against the normal flow of 600-700 GPM from the goaf. It was not a surprise as surges were observed in the earlier longwalls of adjacent mine .Installed the pumping capacity with a factor of safety of 2 to take care of surges.

- It was envisaged to introduce air chilling plant but order could not be placed due to technical reasons. During the working of longwall panel, the face temperatures gradually increased to $32{ }^{\circ} \mathrm{C}$ to $33{ }^{\circ} \mathrm{C}$ with $100 \%$ humidity at support no. 1 and became difficult for workmen to work throughout the shift. The increase in the temperature mainly due to hot strata water at 35 degrees flowing along bottom gate roadways against the incoming air, some of the air is entering in to goaf at Main gate and joining the face from middle of the face to TG with increased temperature and humidity, heat released by freshly cut coal and electricals and longwall machinery. Immediately suppliers of chilling plants were explored and found Aggreko (Pune), who supply surface chilling plants on rental basis. Order is placed and plant was installed on surface in the month of November, 2015.

- The use of diesel vehicles, eliminated the following during installation of longwall face;

- Loading and unloading stations at face.

- Marching of shields in the face and anchoring of dowels in the floor for marching.

- Reduced cycle time for installation of shields and other equipment as the transport was done up to the installation point and lifting, dragging and adjustments were done with diesel vehicles

Transport of mine material and equipment with diesel vehicles has become a way of life.

\section{RECOMMENDATIONS}

The experience of first high capacity longwall face at Adriyala Longwall Project, SCCL is encouraging. Basing on this the following can be taken up:

- Planning bigger panels as in Adriyala where ever clean property is available

- Increasing the extraction height to about $5.0 \mathrm{~m}$ wherever Seam thickness permits.In such case, sufficient reserves will be available to introduce

- Longwalls with an annual capacity of 1.5-3.0MT with panel dimensions of 1.0-1.5 KMs X 150M.

- Planning Longwall Top Coal Caving(LTCC) for thick seams up to $10-12 \mathrm{~m}$. with reduced panel dimensions (No.3 Seam). The Geology will permit to plan such longwalls in most of the places in SCCL and CIL.
Air chilling plants are essential for working beyond $400 \mathrm{M}$ depth. The indigenous suppliers of air chilling plants are not available and need to be developed in India.

Though man riding systems like chair car and chair lift systems are provided in trunk roadways, it is required to provide Diesel cruisers for transport of men. Men transport with Diesel cruisers is very flexible and reach every point in the mine in minimum time. Particularly longwall crew and development crew need to be transported by Mine cruisers to minimize travelling time.

Proper water management is essential for successful operation of longwall. The mine sumps are to be designed with sufficient storage capacity(at least two days capacity) and cleaning arrangements, sufficient dip side development to take care of water surges from longwall and adequate installed pumping capacity. Cleaning chambers along the gate roadways and slurry pumps are to be provided.

All categories of workmen including officers are reluctant to work in underground in general and longwall in particular due to arduous working conditions and long working hours compared with opencast mining. Hence it is required to motivate longwall team to work voluntarily.

\section{CONCLUSION}

Longwall mining is done successfully in all major coal producing countries even indifficult conditionslike highly gassy, hard roof and steeply inclined Seams.It is proved beyond doubt that Longwall as an Underground Mining method is successful in India also where it was introduced with proper spirit. The suitable underground Geological blocks need to be identified for introduction of high capacity longwalls on large scale with the help of Global operators. CIL, SCCL and private operators who are allotted coal blocks for underground coal mining must plan to introduce as many longwall faces as possible and LTCC for thick Seams in the blocks which are feasible for bulk production.

\section{ACKNOWLEDGMENT}

The authors wish to express their sincere appreciation and grateful thanks to themanagement of SCCL for their support and cooperation, for permitting to present this paper andalso permitting to use certain data for presenting in this paper.

\section{REFERENCES}

[1] B. Ramesh Kumar, S Chandrasekhar and B Veera Reddy, "Need to think one step a head -High Capacity Longwalls in India, SCCL experience," in International Mining Conference, New Delhi, India,2015.

[2] SCCL, "Technical reports on strata control" on ALP (R C Frith), SCCL (restricted), 2015. 